\title{
Hairy Indigo Control in Peanut ${ }^{1}$
}

\author{
Jason Ferrell, Blaire Colvin, and Pratap Devkota ${ }^{2}$
}

This publication provides county Extension agents, growers, and pesticide applicators with information on hairy indigo control options in peanut. Information is provided on the postemergence (POST) herbicide options and their control efficacy when applied to hairy indigo at different heights.

Hairy indigo (Indigofera hirsuta) is an annual legume that was introduced to Florida as a forage crop. It has since escaped cultivation and become a troublesome weed in some crop settings. Hairy indigo is particularly difficult to manage in peanut production because control of a legume weed in a legume crop is often challenging.

Hairy indigo germinates in late spring and continues throughout the summer. In general, it is the later-emerging (late May through June) plants that are often the most problematic because many of the postemergence herbicides have already been applied. Hairy indigo commonly grows from $2 \mathrm{ft}$ to $5 \mathrm{ft}$ in height, and the stem becomes increasingly woody with age. As the name suggests, the leaves are covered with a very dense mat of fine hairs that increase in thickness with age.

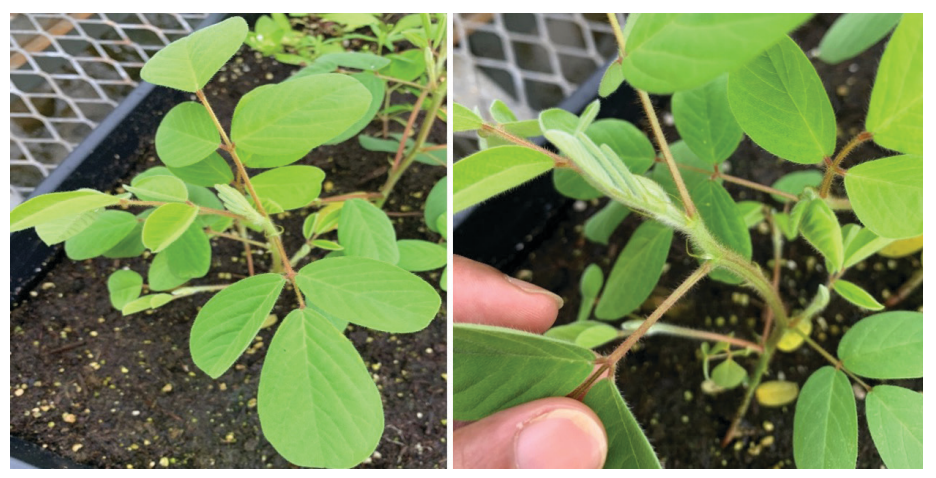

Figure 1. a) Hairy indigo plant. b) Fine hairs cover the leaves and stems of the hairy indigo.

Credit: Pratap Devkota, UF/IFAS

Hairy indigo in peanut can reduce yield in two ways.

1. The plant gains a significant height advantage over peanut and forms a dense canopy. This reduces photosynthesis, but also intercepts fungicide and leads to greater disease incidence.

2. The woody stems of hairy indigo complicate the peanut digging process, and significant peanut yield loss can occur.

1. This document is SS-AGR-387, one of a series of the Agronomy Department, UF/IFAS Extension. Original publication date February 2015. Revised April 2021. Visit the EDIS website at https://edis.ifas.ufl.edu for the currently supported version of this publication.

2. Jason Ferrell, professor, Agronomy Department, and director, UF/IFAS Center for Aquatic and Invasive Plants; Blaire Colvin, former graduate assistant, Agronomy Department; and Pratap Devkota, assistant professor, UF/IFAS West Florida Research and Education Center; UF/IFAS Extension, Gainesville, FL 32611. Original written by Jason Ferrell; revised by Pratap Devkota.

The use of trade names in this publication is solely for the purpose of providing specific information. UF/IFAS does not guarantee or warranty the products named, and references to them in this publication do not signify our approval to the exclusion of other products of suitable composition.

Use pesticides safely. Read and follow directions on the manufacturer's label.

The Institute of Food and Agricultural Sciences (IFAS) is an Equal Opportunity Institution authorized to provide research, educational information and other services only to individuals and institutions that function with non-discrimination with respect to race, creed, color, religion, age, disability, sex, sexual orientation, marital status, national origin, political opinions or affiliations. For more information on obtaining other UF/IFAS Extension publications, contact your county's UF/IFAS Extension office. U.S. Department of Agriculture, UF/IFAS Extension Service, University of Florida, IFAS, Florida A \& M University Cooperative Extension Program, and Boards of County Commissioners Cooperating. Nick T. Place, dean for UF/IFAS Extension. 


\section{Control}

Few soil-applied herbicides have been found to adequately control hairy indigo. In addition, the plant has a long germination window, which generally means that preemergence herbicide applications do not provide adequate control. Postemergence herbicides were tested to determine which program would adequately control hairy indigo in peanut production. The experiment was conducted at the UF/IFAS with five herbicide combinations on hairy indigo at 1-2 inches, 2-4 inches, and 4-6 inches in height. All herbicides were applied with crop oil at $1 \% \mathrm{v} / \mathrm{v}$.

Hairy indigo control at 4 weeks after treatment (WAT), when sprayed at 1-2 inches, was acceptable for all herbicides tested (Table 1). Cadre alone provided a modest $78 \%$ control, but the treatments containing Cobra or Storm provided $90 \%$ control or higher. Surprisingly, spraying hairy indigo at 2-4 inches in height dramatically reduced control for most of the herbicide treatments. This small difference in plant height reduced control by $12 \%$ to $32 \%$. As the plants reached 4-6 inches in height, the control with Cadre alone decreased to $42 \%$ at 4 WAT. However, control from the Cobra and Storm treatments stayed relatively stable (> 70\%) as height increased from 2-4 inches to 4-6 inches.

The rapid reduction in herbicide activity was somewhat expected, because the density of leaf hairs increases rapidly as the seedling establishes and plants start to grow thereafter. The thick hairs intercept the herbicide and prevent the herbicide absorption into the leaf.

\section{Conclusion}

These results indicate that hairy indigo is a weed that can be managed with currently available peanut herbicides. However, if hairy indigo has been a problem in peanut production, it is essential to scout these fields often and spray herbicides when weeds are small. Note that applications of Cobra should be used with caution if the peanut is 8 weeks or older. Numerous trials have shown that yield reduction will commonly occur if Cobra is sprayed after peanuts reach 8 weeks. If hairy indigo is present at the late season, it would be advisable to use Storm $+2,4$-DB to manage this weed.

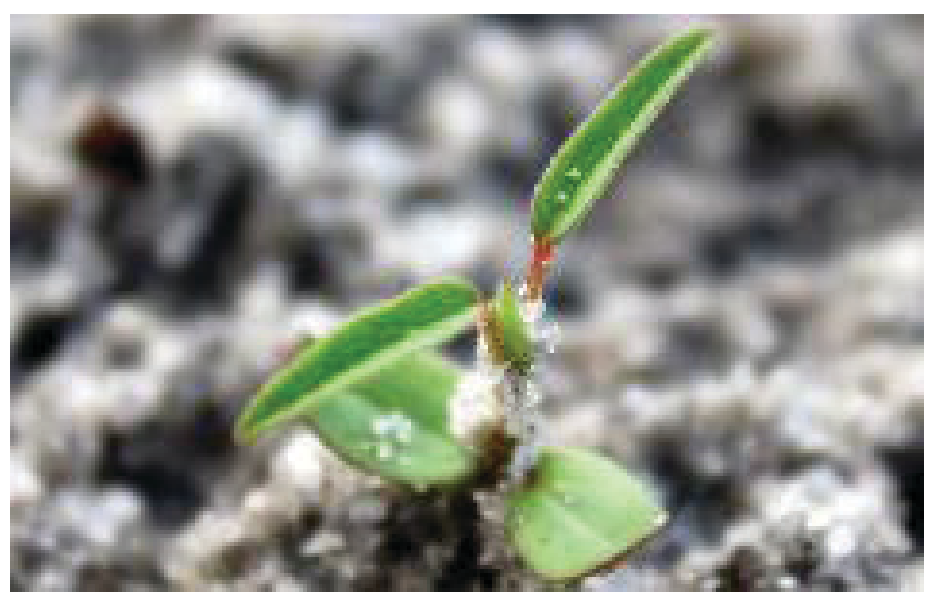

Figure 2. Herbicide treatment was most effective when applied to hairy indigo at plant heights of 1-2 inches.

Credit: Blaire Colvin, UF/IFAS 
Table 1. Hairy indigo control at 4 weeks after treatment when herbicides were applied to weeds at three different heights.

\begin{tabular}{|l|c|c|c|c|}
\hline & & \multicolumn{2}{|c|}{ Hairy Indigo Height (inches) } \\
\hline & & $\mathbf{1 - 2}$ & $\mathbf{2 - 4}$ \\
\hline & Rate (oz/acre) & & \multicolumn{2}{|c|}{ \% control } \\
\hline Cadre & 4 & 78 & 58 \\
\hline Cadre + 2,4-DB & $4+16$ & 88 & 56 & 32 \\
\hline Cobra + 2,4-DB & $12+16$ & 97 & 82 & 30 \\
\hline Cobra + Cadre + 2,4-DB & $12+4+16$ & 99 & 87 & 70 \\
\hline Storm + 2,4-DB & $24+16$ & 90 & 90 \\
\hline
\end{tabular}

Table 2. Postemergence herbicide options (see Table 1 for tank-mix and control efficacy) for hairy indigo control in peanut.

\begin{tabular}{|c|c|c|c|c|}
\hline $\begin{array}{l}\text { Herbicide Active } \\
\text { Ingredient (Trade/ } \\
\text { Product Names) }\end{array}$ & $\begin{array}{l}\text { Mode of } \\
\text { Action Group } \\
\text { (MoA) }\end{array}$ & $\begin{array}{c}\text { Application Rate per A } \\
\text { (Total per A/Season or } \\
\text { Year) }\end{array}$ & $\begin{array}{l}\text { Reentry } \\
\text { Interval } \\
\text { (REI) }\end{array}$ & Specific Comments/Remarks \\
\hline $\begin{array}{l}\text { imazapic } \\
\text { (Cadre or Impose) }\end{array}$ & 2 & $\begin{array}{c}4 \mathrm{fl} \mathrm{oz} \\
(4 \mathrm{fl} \mathrm{oz})\end{array}$ & $12 \mathrm{hrs}$ & $\begin{array}{l}\text { Cadre is very active on small weeds ( } 3-4 \text { inches in size). } \\
\text { Excellent on both purple and yellow nutsedge. Very } \\
\text { good on cocklebur, morningglory species, and wild } \\
\text { radish as well as many other broadleaf weeds. Good } \\
\text { activity on small grass weeds. Cadre has strict rotational } \\
\text { restrictions with respect to following crops, the most } \\
\text { notable of which is an 18-month restriction before } \\
\text { planting cotton. See label for complete spectrum of } \\
\text { control and rotation restrictions. Do not apply within } 90 \\
\text { days of harvest. Cultivation } 10-21 \text { days after application } \\
\text { may provide additional control under drought } \\
\text { conditions. }\end{array}$ \\
\hline $\begin{array}{l}2,4-\mathrm{DB} \\
(2,4-\mathrm{DB} \text { Several brands) } \\
1.75 \mathrm{EC} \\
\text { or } \\
2.0 \mathrm{EC}\end{array}$ & 4 & $\begin{array}{c}\text { 9-18 } \mathrm{fl} \text { oz } \\
\text { (max. of } 2 \text { applications per } \\
\text { year) } \\
\text { or } \\
8-16 \mathrm{fl} \text { oz } \\
\text { (max. of } 2 \text { applications per } \\
\text { year) }\end{array}$ & $48 \mathrm{hrs}$ & $\begin{array}{l}\text { Provides control of morningglory, sicklepod, and } \\
\text { cocklebur. Poor control of Florida beggarweed and } \\
\text { hairy indigo if applied alone. Apply } 2-12 \text { weeks after } \\
\text { planting. Do not apply to drought-stressed peanuts. Do } \\
\text { not apply within } 30 \text { days of harvest. }\end{array}$ \\
\hline $\begin{array}{l}\text { lactofen } \\
\text { (Cobra) }\end{array}$ & 14 & $\begin{array}{c}8-12.5 \mathrm{fl} \mathrm{oz} \\
(25 \mathrm{fl} \mathrm{oz})\end{array}$ & $12 \mathrm{hrs}$ & $\begin{array}{l}\text { Good to excellent control of morningglory, pigweed, } \\
\text { hemp sesbania, and other broadleaf weeds. Apply after } \\
\text { peanuts have } 6 \text { true leaves. An adjuvant must be used. } \\
\text { Any adjuvant may be selected, but oil-based products } \\
\text { will increase peanut injury and weed control relative } \\
\text { to nonionic surfactants. Do not apply within } 45 \text { days of } \\
\text { harvest. }\end{array}$ \\
\hline $\begin{array}{l}\text { bentazon + acifluorfen } \\
\text { (Storm) }\end{array}$ & $6+14$ & $\begin{array}{l}1.5 \mathrm{pt} \\
(3 \mathrm{pt})\end{array}$ & $48 \mathrm{hrs}$ & $\begin{array}{l}\text { Prepackage mix of bentazon + acifluorfen. Apply when } \\
\text { weeds are small and actively growing from cracking } \\
\text { stage up to } 75 \text { days before harvest. Add } 1 \text { pt/A of a crop } \\
\text { oil concentrate. }\end{array}$ \\
\hline
\end{tabular}

